Article

\title{
Exploring the Policy Implications of the Surface Mining Control and Reclamation Act
}

\author{
Ryan M. Yonk 1,2,*iD, Josh T. Smith ${ }^{2}$ and Arthur R. Wardle ${ }^{2}$ \\ Political Science, Utah State University, Logan, UT 84323, USA \\ 2 Economics and Finance, Utah State University, Logan, UT 84323, USA; smithtjosh@gmail.com (J.T.S.); \\ arthur.wardle@aggiemail.usu.edu (A.R.W.) \\ * Correspondence: ryan.yonk@usu.edu; Tel.: +1-435-232-5916
}

Received: 30 October 2018; Accepted: 18 January 2019; Published: 25 January 2019

\begin{abstract}
This paper explores how policy structure, institutions, and political climate impact the ability of the Surface Mining Control and Reclamation Act (SMCRA) to ensure the reclamation of surface coal mines. We conduct a policy review that traces the impacts of the three parts of SMCRA; Reclamation Standards, Reclamation Bonding Requirements, and the Abandoned Mine Land fund. We examine the implications the act and its approach have for the mining industry and their ability to reclaim mining areas. We find that each of the three parts of SMCRA's approach face substantial problems in their implementation. Though largely a positive force for internalizing the environmental costs of surface mining, those issues commonly elucidated in the public choice literature reduce the efficacy of the policy approach and call into question the act's ability to ensure reclamation occurs. Both in the structure of the bonding requirements and in the regulatory structure created by the act, misaligned incentives sometimes hamper effective reclamation. Further, the funds created under SMCRA to reclaim and restore mined lands have often been directed towards projects that are politically expedient for politicians instead of those that would best serve the fund's original reclamation purpose. After revealing these problems and putting them in the context of the public choice literature, we suggest updates to the current policy that would align reclamation incentives and better ensure that the reclamation of surface mines occurs. We emphasize the cooperative elements of SMCRA and suggest how other countries, especially those without major existing frameworks for handling reclamation, can emulate the successes of SMCRA while avoiding its implementations snags.
\end{abstract}

Keywords: mining policy; surface mining; reclamation; bonding requirements

\section{Introduction}

Coal once provided the majority of American energy and still fuels one third of domestic electricity production [1]. Despite its critical role in America's economy, the coal industry has faced substantial pressures in recent years attributed to low coal prices, the rise of natural gas, and mounting regulatory burdens, necessitating widespread financial reorganization. Of the United States' five largest coal companies, one is in bankruptcy, two emerged only a short time ago, and another is examining it as an option [2-6]. Whatever the cause, some environmental groups have raised concerns that bankrupt coal companies will not be able to reclaim their currently operating mines and instead passing those costs to taxpayers [7-9]. The Surface Mining Control and Reclamation Act (SMCRA) provides a number of policy tools used to ensure reclamation of surface coal mines in the United States. The act established a regulatory program that, among other things, detailed the exact reclamation standards that surface coal mines must meet, required financial assurance to guarantee that reclamation would occur in the event of a company shut down, and established the Abandoned Mine Land fund (AML) to pay for reclamation in coal mines that had already been abandoned. This paper explains those tools, assesses 
the effectiveness of their use to date, reviews public choice problems facing U.S. coal reclamation, and offers policy alternatives for mine reclamation in the United States.

\section{Approach and Methods}

Our attempt to understand the implications and effects of SMCRA, like many other attempts to explore public policy, begins with our observation of some curious features of the policy environment and a desire to understand if those curiosities have significant implications for how that policy is implemented and how effective that implementation can be. Thus, our approach is one that begins with the policy as it is and then traces the various features, approaches, and ultimately implications for efficacy that emerge from what we discover.

Our core research question, whether the policy tools established by SMCRA are effective at ensuring reclamation of surface mines, guides our exploration of policy and our evaluation of the policy is considered in light of this core question. Taking this research question as our guide we can limit the scope of our inquiry and still evaluate the totality of SMCRA's efforts to guarantee reclamation of mined lands.

We begin with the policy as written, but concentrate on evaluating the policy as actually implemented. SMCRA was neither written nor implemented in a vacuum and so we trace how it interacts with the wider policy world. We illustrate these interactions with what could be considered case studies of the three key tools SMCRA employs in ensuring reclamation of mined lands.

Our policy tracing approach to exploring and evaluating public policy proceeds in three parts; first we explore the background, motivation, and goals of the policy we are interested in, in this case the reclamation aspects of SMCRA. We then turn to a detailed examination of the policy in light of our core research question and provide a more detailed examination of the core policy instruments. Finally, we suggest an alternative policy approach that builds on the existing regulatory infrastructure but better aligns the incentives for reclamation while operating within the general policy framework we identify through our policy trace.

\section{Background of the Surface Mining Control and Reclamation Act of 1977}

The Surface Mining Control and Reclamation Act of 1977 (SMCRA) is the foundational legislation regulating surface coal mining (as well as surface portions of underground coal mining) in the United States. SMCRA includes a regulatory element, which restricts the activities of surface miners in general, but also includes the standards that reclamation projects must meet. SMCRA requires that coal companies post bonds for mine reclamation and sets up the Abandoned Mine Land fund, which taxes coal producers to pay for reclamation of old abandoned surface mines.

In the years leading up to the 1970s, United States coal production transitioned from being dominated by underground mines to surface mines [10]. Figure 1 illustrates this trend over time. In the midst of this rise in popularity, legislators in the U.S. Congress grew concerned that individual states would engage in a "race to the bottom" by relaxing their mine reclamation rules in order to keep their native coal industries competitive. Critics countered that the environmental effects of surface mining were location-specific and should thus be left to state regulation. The "race to the bottom" concerns combined with the interstate nature of some surface mine pollution ultimately led Congress to begin looking for a solution to the environmental problems of surface mining [11-13]. Early proposals included a full-on ban on surface mining, but consensus soon emerged around proposals for a surface mine regulatory program combined with a funding mechanism for reclaiming abandoned mines [14]. 


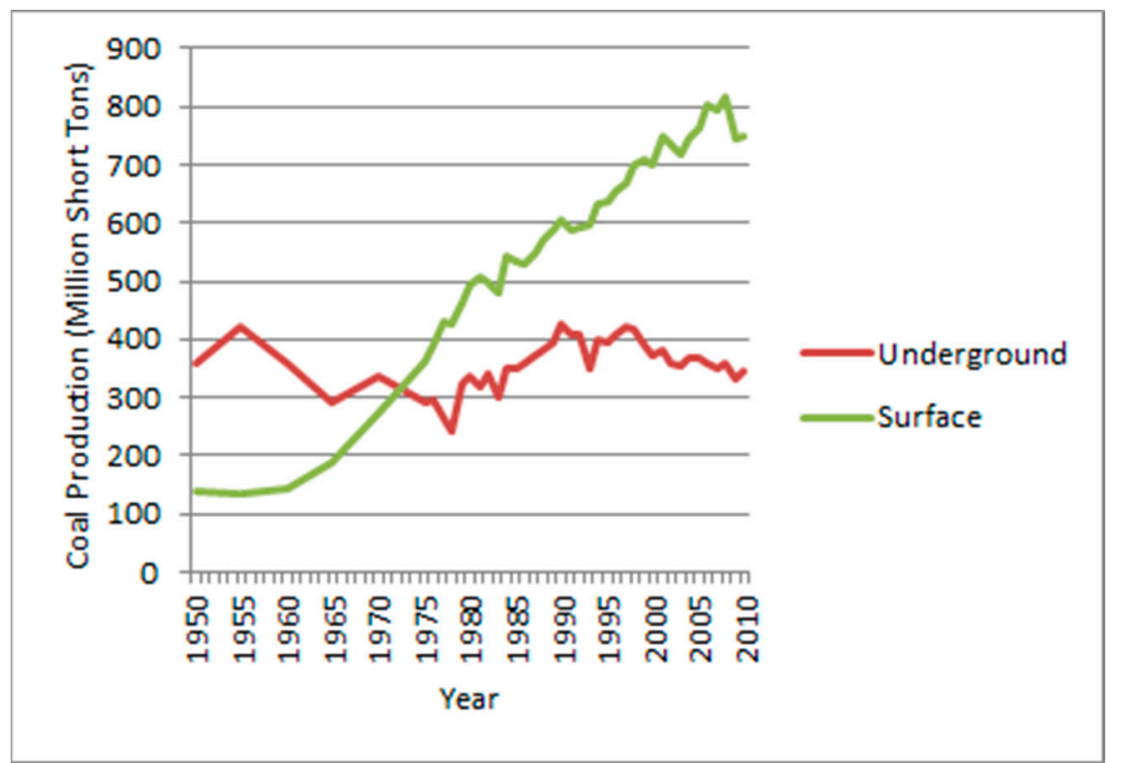

Figure 1. Coal mines by type [10].

Bills resembling the eventual Surface Mining Control and Reclamation Act of 1977 (SMCRA) were passed in the 93rd and 94th Congresses, but both were vetoed by President Ford, who feared the employment and inflation ramifications of the law and also wanted to avoid damaging such a critical domestic energy source [12,14]. After being introduced at the opening of the 95th Congress, SMCRA passed both houses and was signed by President Carter, despite being weaker than he had preferred, and, conversely, more stringent than mining interests desired [12,14]. The bill established the Office of Surface Mining Reclamation and Enforcement (OSMRE) inside the Department of the Interior, which promulgated rules for the enforcement of SMCRA by the end of the decade [15]. The coal industry attempted to counter SMCRA in the courts, arguing that the law violated the 5th and 10th amendments by preempting state control, but those lawsuits were unsuccessful [14]. Today, SMCRA is still the primary law dealing with coal surface mining in general and coal surface mining reclamation in particular. SMCRA handles mine reclamation using three different tools-regulation on mine operations, bonding requirements, and the Abandoned Mine Land fund.

The narrative of SMCRA's passage generally begins with a story of legislative altruism, where individual legislators sought to fight for the common good by tackling surface mining reclamation problems. There is a kernel of truth to this story, but it fails to fully elucidate SMCRA's legislative conception. Kalt and Zupan argue that a purely and narrowly self-interested theory of legislative politics fails to explain SMCRA's passage and that the principal-agent slack offered by democratic political institutions allowed legislators to apply their own ideologies (i.e., conceptions of the "public good") to their voting decisions [16]. Still, Kalt and Zupan conclude only that a purely economic theory of legislative politics fails-they maintain that constituent interests (insofar as they affect reelection odds) play a significant but not all-encompassing role in explaining congressional SMCRA votes [16].

Even if a law is passed purely by the altruistic motives of legislators, political history demonstrates that many public choice failures are born out long after a law's initial passage. SMCRA is no exception.

\section{SMCRA's Policy Approach}

SMCRA regulates many aspects of coal mine operations and includes an extensive section outlining how reclamation must be carried out. While variances are allowed in limited circumstances, the law generally requires all mine operations to return surface mines to their approximate original contour, restore topsoil, isolate mine wastes, and revegetate the area. The law instructs coal miners to conduct reclamation as contemporaneously as practicable [17]. 
SMCRA's regulatory approach is a form of cooperative federalism, developed in an effort to acknowledge that states need primary regulatory authority over surface mining and reclamation because of their differing needs and geographical features [18]. SMCRA also aims to prevent the "race to the bottom" between states by establishing general guidelines that must be met [17]. The act also charges states with monitoring and enforcement $[18,19]$.

The regulations promulgated under SMCRA are implemented and enforced through the Office of Surface Mining Reclamation and Enforcement (OSMRE). The OSMRE works with state permitting organizations to establish a state regulatory program that must be approved by the Secretary of Interior. Once a state's plan is approved, it begins to issue permits and is responsible for enforcement. States that have approved plans are called "primacy states". State permits must meet all of SMCRA's performance standards or states risk losing primacy. As of 2012, 24 states were primacy states [18]. There are currently 12 states that do not have primacy and instead have programs managed by the OSMRE. Of those states, only Tennessee has any ongoing coal mining operations [15,20].

As described by Gresham in 1988 [21], to be approved by the Secretary of Interior, state plans must include:

(1) a state law providing for regulation of mining and reclamation in accordance with the Act;

(2) a state law providing sanctions which meet the requirements of the Act;

(3) a state regulatory authority meeting the requirements of the Act;

(4) a state law providing for an effective permit system;

(5) a process for designation of lands as unsuitable for mining;

(6) a process for review in issuance of permits to avoid duplication with other federal and state agencies; and

(7) rules and regulations consistent with the Secretary's regulations.

These requirements are laid out in SMCRA § 503 [22]. he has,

The Secretary of Interior is explicitly disallowed from approving any program unless she or

(1) Solicited the opinions and publicly disclosed the views of the Administrator of the EPA, the Secretary of Agriculture, and the heads of other relevant federal agencies;

(2) Obtained written concurrence of the Administrator of the EPA with regard to the aspects of the state program that relate to air or water quality;

(3) Held at least one public hearing on the plan in the state;

(4) Found that the state has the legal authority and qualified personnel necessary for the enforcement of the plan's environmental protection standards [22] (30 U.S.C. §§1201-1328 § 503).

As Braverman and Braverman note, SMCRA "affords states comprehensive, but conditional, regulatory jurisdiction within their own borders". State control is limited to state land, however, and they do not manage the permitting process for federal or tribal lands. Instead, OSMRE manages the permitting process in those areas [18].

Cooperative federalism has not always been purely cooperative. State governments often compete with the federal government for control and authority $[11,18,23]$. Vague language creates avenues for OSMRE to argue states have violated SMCRA; for example, there is an active debate on what constitutes appropriate action to remedy problems that the federal OSMRE identifies [18,21,23].

Enforcement of SMCRA's regulations exposes a tradeoff between federal oversight and state control that is sometimes contentious. Braverman and Braverman point to a long-term decline in federal OSMRE inspections as evidence that the relationship may not be as contentious as is sometimes claimed [18]. In 1985, there were 2666 while in 2009, there were only 1469 . They conclude that reductions in federal enforcement indicate that cooperative federalism and conservation has been an overall success. They write, "It appears that the implementation of SMCRA over a thirty-year period 
has ultimately resulted in the state-federal balance that Congress intended when it enacted SMCRA in 1977".

Some research questions the effectiveness of mine reclamation required by SMCRA in restoring the environment $[24,25]$. A 1983 study weighed the costs and benefits of SMCRA and concluded that the costs won out but by a narrow enough margin that "the net effect is probably too close to call" [26]. In contrast, a non-quantitative 1997 article, written by the acting director of the OSMRE at the time, argues SMCRA has been successful in meeting its core goals and should be emulated by future legislation [27]. In this paper we do not explore the technical requirements for reclamation or systematically assess SMCRA's welfare effects. We instead explore the policy requirements for surety guarantees from those engaged in surface mining.

\subsection{Regulatory Concerns}

In general, the regulatory rules and the reclamation efforts by mining companies have been successful at remedying the vast majority of environmental problems introduced by surface mining. Still, the regulatory scheme devised by SMCRA is not perfect and does present problems. Fundamentally, static regulation may freeze outdated environmental policies in place, failing to address dynamic problems.

Concerns about freezing in old practices have been an aspect of SMCRA-centered research since it was first enacted and remain so today. During the interim process of SMCRA's implementation it was criticized for being inflexible and overreaching $[28,29]$. When agencies specify the particular means of achieving certain ends, they effectively outlaw innovation and improvement on those methods. Innovation is discouraged because if a firm invests in finding new ways to reclaim lands that may be more effective and more economical, they will not be allowed to use them [30]. Regulations that freeze the state of the art by requiring it be done a certain way may produce sub-optimal results for both the environment and the mining industry. These results would be in direct conflict with the purpose of SMCRA, which was to protect the environment but not at the detriment of the coal industry [28].

The concerns about freezing outdated reclamation and environmental policies may have been generally voiced during the first phase of SMCRA's implementation when the federal government was managing in every state, but that does not mean that the concerns should be set aside now that states typically manage their own regulatory plans. First, many states still have federal management plans. Past experience indicates that these states could still be subject to the same problems that existed during the interim phase of federal control. Second, because states must implement some aspects of SMCRA that are delegated from the federal government, even states with primacy may suffer from frozen and sub-optimal forms of regulation.

Unfortunately, there is evidence of such freezing of ineffective policies in SMCRA's reclamation regulations. The source of this problem is SMCRA's requirement that reclamation returns mined sites to their approximate original contours, meaning the "lay of the land" must look like it did before mining occurred [25]. While that practice offers some aesthetic benefits, it further disrupts watersheds already disturbed by mining by compacting affected soils. These reclamation practices do not appear to be effective at restoring hydrological features to their pre-mining states. For example, reclaimed areas often have different storm flow responses than watersheds covered with second growth forests. Researchers attribute the differences to the compacted soils at reclaimed sites and in turn ascribe the compacted soil to common practices in reclamation strategies [24,31]. In fact, Ferrari et al. conclude reclamation may effectively return the aesthetics of mined areas to what it was before mining occurred, but, "they do not appear to be effective at restoring key features of the hydrologic regime" [26].

Rules governing return to approximate original contour are only one example of how the inflexibility of regulation can prevent miners from truly restoring environmental quality and instead push them to simply check boxes. These policies help neither the environment nor the mining industry. In lieu of statutory requirements for specific practices in the reclamation process, the rules should require reclamation that reflects the best available science and methods for reclamation. For example, 
the rules requiring that reclamation return the original lay of the land to mined areas could be replaced with the more environmentally responsible requirement that the mined lands be returned to approximately the same environmental state as before mining. That is, that the lands provide similar ecosystem services before and after mining.

\subsection{SMCRA's Bonding Requirements}

To guarantee that the reclamation required in the regulatory section of SMCRA occurs, the law requires mining companies to post a reclamation bond in the form of a corporate surety bond, a collateral bond, a self-bond, or some combination of the three [32]. SMCRA also allows individual states to come up with their own bonding systems to supplant those proffered by federal regulation, though these too are subject to federal oversight. States using their own system generally combine bonding with some form of trust fund paid into on a per-acre basis. As the focus of this report is reforming federal reclamation policy, issues surrounding state systems will not be explored.

\subsubsection{Corporate Surety Bonds}

Surety bonds are third party guarantees, purchased by a mining company, which pay out to the government in the event that a mining company fails to reclaim. Historically, surety bonds have been the preferred form of financial guarantee for many mining operators due to the comparatively small financial outlay they require, freeing more capital for normal business operations [33]. In a 1988 investigation of bonding among four major coal producing states, the Government Accountability Office found that $90 \%$ of the total value of reclamation bonds were surety bonds, though that portion was shrinking even in the late 1980s [34]. Much to the chagrin of the mining industry, the availability of surety bonds for reclamation plummeted in the 2000s as a result of surety industry contraction, new regulations on surety operators, and timidity among government agencies charged with releasing bonds $[33,35]$.

\subsubsection{Collateral Bonds}

Collateral bonds include a variety of financial instruments, including letters of credit, certificates of deposit, cash, or real property. In reality, mining companies utilizing collateral for bonding tend to do so only with letters of credit (see Table 1 below). Because collateral bonds tie up large amounts of capital, they tend to be used only as a last resort, when self-bonding is restricted, and surety bonds are either unavailable or only available on burdensome terms.

\subsubsection{Self-Bonding}

For financially sound companies, the government allows what they call "self-bonding", which is ultimately a guarantee by the company that it will fulfill its reclamation obligations without necessitating further bonding by requiring the pledge of the operators own assets for the completion of reclamation. In short, self-bonds are a calculation by the government that the risk of a company abandoning its mines without reclamation is low enough that external bonding is unnecessary and that sufficient assets exist internal to the company to complete the reclamation requirements. The language of the regulation is below:

"The regulatory authority may accept a self-bond from an applicant for a permit if all of the following conditions are met by the applicant or its parent corporation guarantor [32]:

1. The applicant designates a suitable agent to receive service of process in the State where the proposed surface coal mining operation is to be conducted.

2. The applicant has been in continuous operation as a business entity for a period of not less than 5 years. Continuous operation shall mean that business was conducted over a period of 5 years immediately preceding the time of application. 
i. The regulatory authority may allow a joint venture or syndicate with less than 5 years of continuous operation to qualify under this requirement, if each member of the joint venture or syndicate has been in continuous operation for at least 5 years immediately preceding the time of application.

ii. When calculating the period of continuous operation, the regulatory authority may exclude past periods of interruption to the operation of the business entity that were beyond the applicant's control and that do not affect the applicant's likelihood of remaining in business during the proposed surface coal mining and reclamation operations.

3. The applicant submits financial information in sufficient detail to show that the applicant meets one of the following criteria:

i. The applicant has a current rating for its most recent bond issuance of " $\mathrm{A}$ " or higher as issued by either Moody's Investor Service or Standard and Poor's Corporation;

ii. The applicant has a tangible net worth of at least $\$ 10$ million, a ratio of total liabilities to net worth of 2.5 times or less, and a ratio of current assets to current liabilities of 1.2 times or greater; or

iii. The applicant's fixed assets in the United States total at least $\$ 20$ million, and the applicant has a ratio of total liabilities to net worth of 2.5 times or less, and a ratio of current assets to current liabilities of 1.2 times or greater." The section continues by outlining necessary documentation to prove financial health, allowing corporate guarantors to self-bond other corporation's reclamation work, etc.

Ideally, self-bonding allows financially sound companies to maximize their productivity by allowing them to avoid capital-intensive bonding requirements. For years, self-bonding has done just that-established coal companies with large market capitalizations were able to leverage their existing capital to mine coal very efficiently. However, when the coal industry started facing numerous unanticipated market pressures, the resulting financial distress pushed some companies beneath the financial thresholds required to continue using self-bonding [36]. Despite the downturn, some self-bonded companies continue to meet these requirements.

Table 1. Bond totals for the Top 4 coal producing companies as of 31 December 2015 (in millions) [37-40].

\begin{tabular}{cccc}
\hline Coal Company & Surety Bonds $^{\mathbf{a}}$ & Collaterale Bonds $^{\mathbf{b}}$ & Self-Bonds \\
\hline Peabody Energy & 609.4 & 126.6 & 1403.8 \\
\hline Arch Coal & 188 & 49.2 & 485.5 \\
\hline Cloud Peak Energy & 433.9 & 0 & 200 \\
\hline Alpha Natural Resources ${ }^{c}$ & 399 & $212.2^{\mathrm{d}}$ & 676.1 \\
\hline 2015 Totals & 1630.3 & 388 & 2765.4 \\
\hline
\end{tabular}

a , Also includes bank guarantees, which are reported jointly in 10-K filings; ${ }^{\mathrm{b}}$, Arch Coal, who uses a mix of cash and letters of credit, is the only coal producer that reports using anything other than letters of credit for collateral bonding; ' , Alpha Natural Resources numbers are from 2014- the company has not posted a 10-K filing for 2015; d, Alpha Natural Resources' letters of credit for reclamation are lumped with letters of credit for other purposes, so the amount held for reclamation are lower than this reported number.

The ideal operation of a reclamation bond system like SMCRA's is described in Webber and Webber [41]. They liken reclamation performance bonds to refundable deposits, returnable to the depositee upon successful completion of some action -in this case, reclamation. In requiring a refundable deposit predicated on reclamation performance, SMCRA aligns surface miners' interests with interests of environmental quality. Further, costs of operation are reduced for reliable reclaimers and increased for mine operators notorious for shoddy environmental practice, as surety companies 
will be more willing to offer favorable rates to the former and not the latter. In short, the reclamation bond is a market-based regulation seeking to minimize compliance costs while ensuring adequate environmental outcomes.

Even at the time of Webber and Webber's writing in 1985, it was clear the SMCRA's actual implementation was not ideal [41]. They wrote at length about the prevalence of inadequately small bond amounts being set by state regulators, who tended to over-rely on mine operators for information regarding likely costs of reclamation. In fact, as Galloway and Fitzgerald argued, by allowing state-level regulatory authorities to set bond prices, SMCRA essentially recreated the "race to the bottom" problem in another form [42]. Faulty assumptions built into the OSMRE's Handbook for Calculation of Reclamation Bond Amounts itself are responsible for a portion of the bond underestimation. For example, the law requires bond amounts to be set assuming that the mining operator will follow its mining permit requirements and meet performance standards. In reality, bonds are generally only forfeited after long periods of noncompliance, increasing reclamation costs [43] (p.93). Still, even with these issues, mine operators are better incentivized to reclaim and, according to the National Mining Association, almost 2.6 million acres have been reclaimed and released from bonding since 1978 [44].

There has been little to no formal analysis on the adequacy of surety or collateral bonding since the 1990s. There is evidence, however, that problems associated with state negligence in bond amounts is being dealt with at a federal level. In 2012, the OSMRE found that $80 \%$ of bonds forfeited in Kentucky were not sizable enough to fully cover reclamation costs. The federal government forced Kentucky's Department of Natural Resources, under threat of federal takeover, to remedy the problem [45]. Kentucky has since revised their standards and results are slowly improving [46]. A more recent Government Accountability Office report suggests the problem is still widespread, with $22 \%$ of all bond forfeitures from July 2007 to June 2016 failing to cover reclamation costs [47].

For companies that choose to bond using sureties, availability of those bonds has been an issue for decades. As the length of time a surety bond is required increases, the cost of that bond goes up and the probability that a surety company will even provide a bond goes down, often to the point that surety bonds are completely unavailable. In other words, surety bonds are poorly suited for guaranteeing long term obligations $[33,48]$. As attention to long term environmental risks associated with mining has been piqued, regulators attempting to set bond amounts have extended bond timelines without any real reliance on actual risk projections, instead preferring a precautionary approach. Uncertainty about bond release timing plays a significant role in the lack of surety bond availability and can make surety bonds unaffordable even to the best, most financially sound miners. Regulators are notoriously wary of bond release and often refuse to release any portion of a bond until the entirety of a site is reclaimed [33]. Regulators are incentivized to withhold release- - the longer they can keep a bond active, the less likely some unexpected environmental problem will be uncovered. Industry, on the other hand, needs shorter terms in order to attain bonds at reasonable rates. Surety bonds provide an excellent way of aligning mining and environmental interests when enacted properly, but issues surrounding bond amounts and bond release have prevented SMCRA from fully taking advantage of surety bonds' theoretical advantages.

Concerns associated with self-bonding rose to prominence in the past few years as some of the largest coal producers in the United States with billions of dollars of self-bonds collectively fell under minimum financial thresholds and even filed for bankruptcy. Although SMCRA requires that states revoke the right to self-bond from companies that slip below those financial thresholds (and thus gather the necessary financial assurance from other sources), regulators are reticent in enforcing that requirement [36,49]. That reticence exists for good reason-from a regulator's perspective, it makes little sense to require a previously self-bonded coal company now experiencing financial distress to seek alternative bonding - where would they get it, and at what cost? Forcing a company facing both shaky market conditions and financial challenges to take on hundreds of millions of dollars in liabilities would only further guarantee full-blown financial collapse and increase the possibility of reclamation failure. Regulators themselves have commented on the impropriety of that decision multiple times [36]. 
The amounts of self-bonding obligations in each of the top 4 coal producing companies in the U.S. are repeated below in Table 2 (Murray Energy, the fifth largest, is excluded as it is privately held and thus does not have publicly accessible SEC filings):

Table 2. Bond Totals for the Top 4 Coal Producing Companies in the U.S as of 31 December 2015 (in millions) [37-40].

\begin{tabular}{cc}
\hline Company & Self-Bonds \\
\hline Peabody Energy & 1403.8 \\
Arch Coal & 485.5 \\
Cloud Peak Energy & 200 \\
Alpha Natural Resources ${ }^{\text {a }}$ & 676.1 \\
2015 Totals & 2765.4 \\
\hline
\end{tabular}

a: Alpha Natural Resources numbers are from 2014—the company has not posted a 10-K filing for 2015.

Self-bond numbers this large being at stake in bankruptcy proceedings may seem disconcerting, but these reclamation obligations are only at risk to a limited extent. The bankruptcies hitting the coal industry are Chapter 11, not Chapter 7, meaning their goal is reorganization, restructuring, and eventually continuing operations after being relieved from excessive debt, as opposed to complete dissolution [50]. Alpha's bankruptcy exit plan, for example, requires Alpha to cover most of its previously self-bonded sites by paying into a special trust fund until 2025, with additional funds coming from Alpha's free cash and other reclamation projects being taken on by a new, private company formed by the bankruptcy court out of some of Alpha's pit mines. The agreement led Alpha to assert they are "positioned well to satisfy (our) environmental obligations on an ongoing basis", though some environmental groups are skeptical that the plan will adequately cover reclamation costs [51]. Concerns over Alpha's reclamation obligations were again ignited when the company was sued by West Virginia's Department of Environmental Protection (DEP) for fraud after failing to include $\$ 100$ million in various obligations (some reclamation-related) during its bankruptcy hearings, though that suit was settled to the DEP's satisfaction. Randy Huffman, DEP secretary, said the settlement "ensure(d) reclamation will be done" [52].

Arch Coal, the latest large coal company to emerge from bankruptcy, also included as an integral part of its bankruptcy exit plan to fund all its reclamation obligations and end reliance on self-bonding [53,54]. Importantly, none of the major coal bankruptcies has so far resulted in any formal discharge of reclamation obligations, a perennial fear of many environmentalists. Bankruptcy courts, it seems, are averse to releasing reclamation obligations. Bankruptcy laws relating to environmental remediation are written to incentivize coal companies to continue meeting reclamation obligations, making complete default unlikely. SMCRA even allows the OSMRE to block individual mine managers from getting future permits approved (a practice known as "permit-blocking") if their track record of reclamation compliance is poor due to financial distress [55]. All things considered, the risk to reclamation obligations from Chapter 11 bankruptcies appears minimal.

The possibility of future coal industry failures and then the resulting failure to reclaim mined lands is still worth consideration, even as none of the major coal companies are currently undergoing Chapter 7 bankruptcy. For that reason, the size and extent of the self-bonding problem have led nearly all researchers examining the subject, including the Government Accountability Office, to unimaginatively propose either a complete cancellation or significant drawdown of the use of self-bonds, see e.g., $[36,47,56]$. Our own analysis suggests at least one alternative to these more drastic measures exists.

\subsection{Public Choice Issues in Bonding}

On coal producers' side, bonding requirements buttressed by the previously-discussed regulatory requirements act as a solid incentive to ensure coal companies conduct adequate reclamation. 
As described earlier, Webber and Webber illuminate why surety bonding provides such an effective incentive to miners: it puts financial capital at risk if reclamation does not occur and allows surety companies to adjust the costs of bonding according to the riskiness of an operator [41].

The incentives facing governments are not as clear or robust. States seeking to attract coal development (or, more likely, the economic stimulus that coal development creates) are incentivized to underestimate bond amounts, leaving states with unfunded reclamation obligations in the case of a coal company failure. While SMCRA certainly alleviated this problem considerably, underestimation of bond amounts by states mirrors the original "race to the bottom" concerns that led to SMCRA in the first place.

Self-bonding has turned out to be another matter entirely, with ambiguous incentives for both parties. For coal producers, reclamation is still necessary in order to stay in business and avoid the risk of permit suspension. Since reclamation is not externally bonded, there is little financial reason to conduct reclamation efforts if company dissolution is on the immediate horizon. This leaves reclamation unfunded outside of what the bankruptcy court is willing to secure in the course of company dissolution.

For companies facing significant financial challenges, regulators are put into a tough spot. Not wanting to send companies further into financial distress and potentially into bankruptcy and ultimately removing most incentives to reclamate, bureaucrats instead allow self-bonders to continue operating despite likely failing to meet self-bonding requirements.

A creative solution designed to better ensure reclamation occurs with minimal impact on taxpayers is needed.

\section{A Potential Alternative Policy Approach: The Abandoned Mine Land Fund}

Just as SMCRA's regulatory and bonding requirements seek to enforce reclamation for operating mines, the Abandoned Mine Land (AML) fund seeks to reclaim old, abandoned mines. Specifically, the program deals with coal mines that had already been abandoned before SMCRA's passage in 1977, though the program was later expanded to include mines abandoned between 1977 and whenever a state gained primacy and mines bonded by surety companies that went out of business [57]. To fund that reclamation, the law placed a production tax on all coal mined in the U.S. to be paid into the new fund. In a complex system of cooperative federalism, the law allowed individual states to craft their own abandoned mine reclamation programs, funded out of the federal program. Since its inception in 1977, the AML fund has collected over $\$ 10.7$ billion but disbursed only $\$ 8.3$ billion, leaving an unappropriated balance of $\$ 2.5$ billion, almost a quarter of all funds collected since 1977 [58] (numbers do not sum due to rounding error).

For a few reasons, there has been no study formally addressing the macro-level extent to which the AML program has ameliorated the United States' abandoned mine problem. For one, environmental quality in general is difficult to quantify and compare, making quantitative analysis of AML successes challenging. More importantly, there is nobody that knows the location and extent of every abandoned mine site that needs reclamation work. Although the OSMRE attempts to document the existence of every high priority site that endangers human health or safety, that excludes billions of dollars worth of reclamation sites. Many states have not comprehensively updated their abandoned mine site inventories since the 1970s or 1980s, allowing decades of time to exacerbate problems through subsidence, blowouts, or sinkholes without any update to the inventory system. These and other abandoned mine site inventory problems are documented by [59]. Illustrating the extent of the inventory problem, the Bureau of Land Management attempted to quantify the amount of abandoned mine sites existing on BLM land in California, Nevada, and Utah that had not yet been inventoried. They estimated that 92,693 sites and 367,748 features were still missing from inventory lists and that it would take 20 years and cost $\$ 212$ million to assemble a comprehensive index [60]. For those sites that are inventoried, the severity of reclamation problems are sometimes overstated, a symptom of states being incentivized to maximize their ability to draw from the AML fund [43] (p. 258). 
Smaller studies have attempted to measure the success of the AML program over smaller areas. Wei, Wei, and Viadero conducted watershed analysis with varying levels of AML program involvement and found that AML penetration was significantly associated with water quality improvement over a variety of measures, though it did not help in addressing low $\mathrm{pH}$ levels characteristic of mine-polluted waters [61]. Mishra, Hitzhusen, Sohngen, and Guldmann estimate the societal benefits of AML mine reclamation in a lake region of Ohio, based on costs and benefits of past projects [62]. They claim that the recreation benefits gained from increased water quality outweigh the costs associated with the necessary abandoned mine reclamation. Overall, the AML has been used to reclaim almost 800,000 acres of impacted land and water [59].

\subsection{The Diversion of Reclamation Funds}

The AML fund was originally narrowly designed to help reclaim surface coal mines abandoned before 1977. While that is still the predominant use of AML funding, the scope of the AML's distributions has slowly widened.

\subsubsection{Funding Union Benefits}

The most obvious diversion of reclamation funding out of the AML goes towards health and pension benefits for the United Mine Workers of America (UMWA). In 1990, Congress passed an act that allowed the AML fund to begin collecting interest on its funds in 1992. The Energy Policy Act of 1992 then allowed up to $\$ 70$ million of that interest to be transferred to the UMWA's combined benefit fund, which provides health benefits to mine retirees whose companies have since gone out of business [63]. In 2006, the $\$ 70$ million cap was removed, and the AML fund was diverted to even more UMWA health plans [64]. For reference, $\$ 31.8$ million was diverted from the AML to pay for UMWA benefits in 2015 [65] (p. 39). Ensuring that health benefits are available for retired miners is a noble aim, it does not further the goal of mine reclamation. This is compounded by the fact that hardly any of the coal producers currently paying into AML fund are members of the UMWA. In fact, only 9\% of coal production in 2015 came from UMWA producers [66].

Diversions from the fund into miner retiree benefits are ongoing, proposed on an almost annual basis. The Miners Protection Act, introduced by Senator Joe Manchin of West Virginia in 2015 and by Senator Orrin Hatch of Utah in 2016, seeks to broaden the AML funds available to UMWA benefits programs [67]. Fortunate for the AML, that legislation is not expected to be successful [68]. Still, these developments illustrate that the AML has been consistently targeted as a funding source for non-reclamation programs.

\subsubsection{Non-Coal Mine Reclamation}

Both SMCRA and the AML are indisputably focused on coal mining issues, but the law allows spending AML money on non-coal mines in limited circumstances, such as in emergency situations and when all coal reclamation projects within a state have already been reclaimed. Wyoming, Montana, and Louisiana claimed to be done with coal reclamation early in the life of the law, and that claim was uncritically accepted by the OSMRE, allowing the states to spend the state share of their funds on some non-coal reclamation projects. A later Government Accountability Office report revealed their claims to be false, the amendment to rectify the apparent misunderstanding included a grandfather clause allowing Wyoming, Montana, and Louisiana to continue spending on non-coal mine projects [69].

\subsubsection{Unrelated State Spending}

Individual states have also been guilty of repurposing their AML allocations towards blatant non-reclamation uses. Wyoming's misuse of funds, which diverted AML money towards road construction and municipal water projects, resulted in their AML allocation being cut from $\$ 150$ million to $\$ 13.5$ million in 2013. This change was spurred by a cap of $\$ 15$ million created by Congress [70]. According to the Wyoming Taxpayers Association, coal companies in Wyoming have contributed 
about $\$ 3$ billion to the AML and about $\$ 1$ billion of that has been reallocated to Wyoming [70]. Still, the Wyoming legislature plans to continue spending money on even more unrelated projects such as a stream rerouting [71]. Wyoming's projects may be the only widely-reported examples of such misuse, but that may stem from efforts to purposefully hide state-level fund diversion. It is difficult to monitor whether every individual reclamation project is appropriate, making it likely that this is a more widespread phenomenon. A 1991 Government Accountability Office [72] report claimed that states were spending money nearly perfectly in line with AML objectives, suggesting that misuse is a new, modern problem, rising as the amount of severe abandoned mine reclamation work to be done within a state diminishes to zero.

An updated Government Accountability Office investigation could clarify the extent of fund-raiding in AML funds. An updated 2017 report by the Department of the Interior's Inspector General concluded that OSMRE has not used its oversight authority, did not enforce state reclamation plans, and that the OSMRE was unable to account for AML hazards. Further, the report pointed to large administrative costs in Mississippi and Louisiana and yet no reclamation work [73]. These issues suggest serious concerns for SMCRA's ability to fulfill the environmental goals its authors desired.

\section{Policy Recommendations}

The Surface Mining Control and Reclamation Act of 1977's statement of purpose requires that the act serves to "assure that the coal supply essential to the Nation's energy requirements, and to its economic and social well-being is provided and strike a balance between protection of the environment and agricultural productivity and the Nation's need for coal as an essential source of energy" [22]. The interest of the coal industry must not allow the OSMRE to override environmental prudence, but SMCRA establishes quite clearly that environmental considerations ought to be taken with an eye towards industry impact. Many lists of policy recommendations have been proposed, see e.g., [36] (see p. 55), but few consider industry and bureaucratic incentives with appropriate gravitas. In this section we suggest policy changes within the larger SMCRA policy environment that if implemented in whole or in part, will serve to better align the incentives created by SMCRA to allow both the continued existence of the coal industry and the continued reclamation of mines, both new and long abandoned.

\subsection{Expand the AML's Ability to Reclaim Coal Mines While Restraining Its Misuse}

Addressing the immediate concerns related to self-bonding and the problems surrounding the issuance of other bonds is of paramount importance. The AML holds a huge, currently unappropriated surplus. While the fund is currently being siphoned by non-reclamation activities like UMWA benefits, it is not allowed to cover reclamation for post-1977 mines when SMCRA's reclamation and boding provisions are not enough. Opening up the use of the AML to cover reclamation for mines when both the regulatory and bonding elements of SMCRA fail will protect the public from paying for reclamation through taxes. Coal companies with large self-bond holdings have paid into the AML for years-drawing upon AML resources to insure their bonds still, in effect, means that those companies covered their own reclamation and then some. A potential limitation is that the value of total outstanding self-bonds exceeds the size of the surplus in the AML (to say nothing of surety and collateral bonds). Our review of the literature, however, gives ample reason to doubt that such a sum will need to be covered, as relatively small numbers of reclamation projects are not completed by the operator in the normal course of business operations. Regulators at OSMRE should bear this concern in mind and monitor the relative size of AML funds and reclamation obligations.

Given the size of the AML's $\$ 2.5$ billion unappropriated balance, the limited extent of unrelated fund-raiding is actually quite miraculous, but that miracle cannot be expected to last forever. As with any large pot of unappropriated money, this fund is likely to draw politicians, bureaucrats, and rent-seekers hungry for funding. Allowing the extra balance to be utilized for reclamation rather than funding projects unrelated to coal reclamation (such as UMWA health benefits, non-coal reclamation, and miscellaneous public works projects) would allow AML money to be spent in a fashion closer 
to Congress' original intent. This is similar to the 2017 Inspector General's recommendation that coal-related reclamation be prioritized and funds only spent on non-coal reclamation after prioritized coal projects are completed. Both our recommendation and the Inspector General's properly focus on ensuring that the environmental harms of surface mining are internalized to the industry responsible for them.

Expanding AML fund use to insuring self-bonds may re-entrench a moral hazard for state politicians and bureaucrats who underestimate bond costs, now thinking that any slack will be picked up by the AML. This hazard can be counteracted by taking reclamation costs for failed bonds out of the state share of AML funding, which would act as a powerful deterrent and mitigate the concern.

To further ensure that AML fund use is limited to reclamation, the fund would benefit from more stringent congressional oversight. Current misuse of AML funds is limited but curtailing these infractions would serve to protect the fund from future raids.

If current revenues in the AML prove insufficient to cover the reinsurance of the self-bonders, the coal production tax funding the AML could also be raised. Due to the surplus currently being held in the fund, such an increase is unlikely to be necessary. Further, in keeping with SMCRA's eye towards coal industry health, tax increases should be made with only with proper consideration of mine finances.

\subsection{Reform Bond Valuation and Release}

A second recommendation focuses on improving the reclamation bonding process given that some evidence of inadequate bond amounts has been found and correct bonding amounts are of particular importance to ensuring reclamation. Similarly, companies that do not meet the requirements for self-bonding are sometimes allowed to do so because regulators lack the expertise to properly judge financial health. In both cases, reclamation would be more secure if regulators outsourced bond amount setting and self-bonding standard compliance to independent third parties. Independent third parties can limit the bureaucratic incentive problems identified earlier-namely that state regulators have an incentive to expand their domain of control by allowing questionable bonds to pass through regulatory channels unchallenged.

If setting bond amounts higher and being stricter about self-bonds increases costs to miners, then the OSMRE could unilaterally decrease the costs associated with bonding without any decline in the quality of environmental benefits of reclamation by offering more certainty to surety companies. Certainty can be created by drafting unambiguous and binding procedures for bond release. Current regulations are vague and allow regulators much leeway to require bonding indefinitely for small risks of long-term environmental damages, with drastic consequences for bonding expenses. Regulators are risk averse and hold bonds longer than necessary because of an incentive to protect themselves.

Reinsuring bonds (both surety and self) with the AML would help to address the issue of bond release as well. Multiple scholars examining bond release problems have suggested using trusts to financially guarantee long term pollution or reclamation problems [33,48]. Trusts allow uncommon risks to be pooled, making sure the necessary reclamation occurs without placing onerous financial obligations on any one party. The AML, if retooled according to these proposals, would mimic the function of a trust and allow American reclamation to reap these benefits.

\subsection{Implications for Future Resource Extraction Policy and Policy Diffusion}

A substantial body of research finds that developing countries lack environmental regulations or enforcement, and that few innovative attempts at regulation have been attempted, and thus, our investigation of the United States' experience with SMCRA reveals several potential policy concerns for developing countries. These range from concerns about regulatory freezes and apparent but actually absent oversight. For example, past research points to SMCRA as a positive example for developing countries. One paper contrasts SMCRA's detailed approach with South Africa's regulations that do not include specific requirements to return mined land to its prior condition [74], yet it does so without 
reference to the regulatory freeze issues that threaten the environmental effectiveness of SMCRA's more explicit requirements. The research on SMCRA suggests that it is an overall benefit, but if it is to be offered as a potential model for others to follow, then its failings should also be in full view so that policymakers in developing countries can avoid them [74-77].

Considering that recent literature points to SMCRA as a guide for future policy in other countries, clarifying what it accomplishes effectively and where its implementation can be improved is a vital effort for policymakers interested in environmental protection and reform [78]. Here our review of SMCRA shows that the insights from public choice scholarship are particularly valuable. Regulators in developing countries should carefully consider the incentives that they create through their mining reclamation requirements and bonding policies as well as the incentives for outside groups to attempt to raid the funds collected under their version of the AML fund.

Other research on resource extraction should be applied to issues in developing countries as well. For example, recent work suggests that surety bonds are effective at internalizing environmental costs in the oil and gas field [79]. Although a separate industry, the insight that bond requirements prevent environmental damage by screening out firms who are at a high risk of default applies in any extractive industry. Simple rules requiring that companies clean up after themselves and be required to have the funds to do so either through bonds or insurance requirements are effective implementations of market-based environmental policy.

Our final note about policy diffusion is that SMCRA struck a balance between coal's role in powering the United States and requiring that the coal industry also mitigate the environmental harms that it creates. Ensuring that environmental costs are accounted for should be the cost of doing business for extractive industries.

\section{Conclusions}

Our examination of the reclamation policy instruments included in the Surface Mining Control and Reclamation act highlights how policy instruments that appear well constructed and seem to meet the usual tests for making successful public policy can misalign incentives when implemented in the real world. Each of SMCRA's key policy tools (regulatory requirements, bonding requirements, and the Abandoned Mine Lands fund) provide incentives to ensure reclamation occurs. These attempts, however, are not immune to the public choice realities that often emerge from public policy. In important ways, SMCRA creates misaligned incentives for both the regulating agency and industry. These misaligned incentives leave open the possibility for reclamation to be inadequate or absent altogether. We suggest that an update to SMCRA's policy approach is in order to better align incentives of regulators and miners.

Author Contributions: Each of the authors worked jointly on all aspects of this project.

Funding: This research received no external funding.

Conflicts of Interest: The authors declare no conflict of interest.

\section{References}

1. Energy Information Administration. Electric Power Monthly-Table 1.1 Net Generation by Energy Source: Total (All Sectors) 2006. Available online: http:/ / www.eia.gov/electricity/monthly / epm_table_grapher. cfm?t=epmt_1_01 (accessed on 9 December 2018).

2. Chaney, S. Arch Coal Emerges from Chapter 11. The Wall Street Journal. Available online: http://www.wsj. com/articles/arch-coal-emerges-from-chapter-11-1475684184 (accessed on 9 December 2018).

3. Mooney, C.; Mufson, S. How Coal Titan Peabody, the World's Largest, Fell into Bankruptcy. The Washington Post. 2016. Available online: https:/ /www.washingtonpost.com/news/energy-environment/wp/2016/ 04/13/coal-titan-peabody-energy-files-for-bankruptcy/ (accessed on 9 December 2018). 
4. Hals, T.; Rucinski, T. Coal Miner Alpha Emerges from Bankruptcy Amid Doubts on Outlook; Reuters: London, UK, 2016; Available online: http:/ / www.reuters.com/article/us-alpha-natural-bankruptcy-idUSKCN1062Q0 (accessed on 9 December 2018).

5. Kazin, M. Murray Energy CEO: Bankruptcy Is Possible for Us. Fox Business. Available online: http:/ / www. foxbusiness.com/features/2016/07/06/murray-energy-ceo-bankruptcy-is-possible-for-us.html (accessed on 9 December 2018).

6. Energy Information Administration. Annual Coal Report-Table 10 Major U.S. Coal Producers. Available online: https:/ / www.eia.gov/coal/annual/pdf/table10.pdf (accessed on 9 December 2018).

7. Malone, J.; Winslow, T. Financial Assurance: Environmental Protection as a Cost of Doing Business. 2018. Available online: https://law.und.edu/_files/docs/ndlr/pdf/issues/93/1/93ndlr1.pdf (accessed on 9 December 2018).

8. Cosier, S. Who Pay for Mine Cleanup after Big Coal Goes Bankrupt? Natural Resources Defense Council: on Earth. 2016. Available online: https://www.nrdc.org/onearth/who-pays-mine-cleanup-after-big-coalgoes-bankrupt (accessed on 9 December 2018).

9. McGinley, P. Will Taxpayers Foot the Cleanup Bill for Bankrupt Coal Companies? The Conversation. Available online: http://theconversation.com/will-taxpayers-foot-the-cleanup-bill-for-bankrupt-coalcompanies-56415 (accessed on 9 December 2018).

10. Energy Information Administration. Annual Energy Review-Table 7.2 Coal Production, Selected Years 1949-2011. Available online: http:/ / www.eia.gov/totalenergy/data/annual/pdf/sec7_7.pdf (accessed on 9 December 2018).

11. Udall, M.K. The enactment of the Surface Mining Control and Reclamation Act of 1977 in retrospect. West Virg. Law Rev. 1979, 81, 553-557.

12. Desai, U. The politics of federal-state relations: The case of surface mining regulations. Nat. Resour. J. 1991, 31, 785-802.

13. Beck, R.E. Setting the course for the Surface Mining Control and Reclamation Act of 1977. Nat. Resour. Environ. 1995, 10, 24-76.

14. Waters, R.A. A summary of the legislative history of the Surface Mining Control and Reclamation Act of 1977 and the relevant legal periodical literature. West Virg. Law Rev. 1979, 81, 775-783.

15. Office of Surface Mining Reclamation and Enforcement. Chronology of Major SMCRA-Related Events. 2016. Available online: http://www.osmre.gov/lrg/chronlisting.shtm. (accessed on 9 December 2018).

16. Kalt, J.P.; Zupan, M.A. Capture and ideology in the economic theory of politics. Am. Econ. Rev. 1984, 74, 279-300.

17. Permanent Program Performance Standards-Surface Mining Activities, 30 CFR 816. Available online: https: / / www.law.cornell.edu/cfr/text/30 / part-816 (accessed on 9 December 2018).

18. Braverman, S.C.; Braverman, M.R. Regulation of surface coal mining: The end of a thirty-year balancing act. Nat. Resour. Environ. 2012, 27, 28-35.

19. State Regulatory Authority: Inspection and Enforcement, 30 CFR 840. Available online: https: / /www.law. cornell.edu/cfr/text/30/part-840 (accessed on 9 December 2018).

20. Office of Surface Mining Reclamation and Enforcement. Frequently Asked Questions. 2016. Available online: http:/ / www.osmre.gov/ resources / faqs.shtm (accessed on 9 December 2018).

21. Gresham, T. Federal notices of violation in primacy states: Oversight or overkill? J. Miner. Law Policy 1988, 3, 375-415.

22. Surface Mining Control and Reclamation Act of 1977. Available online: https://www.fws.gov/laws/ lawsdigest/surfmin.html (accessed on 9 December 2018).

23. Green, E.M.; Price, L.A.; McGinley, P.C.; Miller, D.M.; McCarthy, G.M. The Surface Mining Control and Reclamation Act of 1977: New Era of Federal-State Cooperation or Prologue to Future Controversy? Eastern Mineral Law Institute: Morgantown, WV, USA, 1997.

24. Baxter, B.N. Cause and effect: surface mine reclamation and flood litigation in Appalachia. Ky. J. Equine Agric. Nat. Resour. Law 2012, 4, 135-154.

25. Ferrari, J.R.; Lookingbill, T.R.; McCormick, B.; Townsend, P.A.; Eshleman, K.N. Surface mining and reclamation effects on flood response of watersheds in the central Appalachian Plateau region. Water Resour. Res. 2009, 45. [CrossRef]

26. Kalt, J.P. The costs and benefits of federal regulation of coal strip mining. Nat. Resour. J. 1983, 23, 893-915. 
27. Henry, K.L. Coal mining in the United States: SMCRA"s successful blueprint. Nat. Resour. Environ. 1997, 11, 7-61.

28. Gage, R.J. The failure of the interim regulatory program under the Surface Mining Control and Reclamation Act of 1977: The need for flexible controls. West Virg. Law Rev. 1979, 81, 595-625.

29. Hackworth, Z.J.; Lhotka, J.M.; Cox, J.J.; Barton, C.D.; Springer, M.T. First-Year Vitality of Reforestation Plantings in Response to Herbivore Exclusion on Reclaimed Appalachian Surface-Mined Land. Forests 2018, 9, 222. [CrossRef]

30. Wiener, J.B. The regulation of technology, and the technology of regulation. Technol. Soc. 2004, 26, 483-500. [CrossRef]

31. Negley, T.L.; Eshleman, K.N. Comparison of stormflow responses of surface-mined and forested watersheds in the Appalachian mountains. Hydrol. Process. 2006, 20, 3467-3483. [CrossRef]

32. Bond and Insurance Requirements for Surface Coal Mining and Reclamation Operations Under Regulatory Programs, 30 CFR 800. 2016. Available online: https:/ / www.law.cornell.edu/cfr/text/30/part-800 (accessed on 9 December 2018).

33. Kirschner, K.A.; Grandy, E.B. Mining and the vanishing surety bond market. Nat. Resour. Environ. 2003, 17, 152-189.

34. Government Accountability Office. Cost and Availability of Reclamation Bonds (GAO Publication No. B-229961). 1988. Available online: http://www.gao.gov/assets/150/146314.pdf (accessed on 9 December 2018).

35. Orlando, M.J. Financial Assurance for Environmental Protection: Trends and Opportunities (PERC Research Paper No. 12-17). Available online: http:/ / papers.ssrn.com/sol3/papers.cfm?abstract_id=2141337 (accessed on 9 December 2018).

36. Hein, J.F.; Snow, B.; Stefanik, S.; Webb, L. Self-Bonding in an Era of Coal Bankruptcy: Recommendations for Reform; Institute for Policy Integrity: New York, NY, USA, 2016; Available online: http:/ / policyintegrity.org/files/ publications/Coal_Self-Bonding_Report.pdf (accessed on 9 December 2018).

37. Peabody Energy Corporation. 10-K Annual Report 2015. Available online: http:/ /www.peabodyenergy. com/content/162/sec-filings (accessed on 9 December 2018).

38. Alpha Natural Resources, Inc. 10-K Annual Report 2015. Available online: http://ir.alphanr.com/docs.aspx? iid $=4100842$ (accessed on 9 December 2018).

39. Arch Coal, Inc. 10-K Annual Report 2015. Available online: investor.archcoal.com/phoenix.zhtml?c= 107109\& $\mathrm{p}=$ irol-sec (accessed on 9 December 2018).

40. Cloud Peak Energy Inc. 10-K Annual Report 2015. Available online: http://investor.cloudpeakenergy.com/ sec-filings (accessed on 9 December 2018).

41. Webber, B.S.; Webber, D.J. Promoting economic incentives for environmental protection in the Surface Mining Control and Reclamation Act of 1977: An analysis of the design and implementation of reclamation performance bonds. Nat. Resour. J. 1985, 25, 389-414.

42. Galloway, L.T.; FitzGerald, T.J. The bonding program under the 1977 Surface Mining Control and Reclamation Act: Chaos in the coalfields. West Virg. Law Rev. 1987, 89, 675-698.

43. McElfish, J.M.; Beier, A.E. Environmental Regulation of Coal Mining: SMCRA's Second Decade; Environmental Law Institute: Washington, DC, USA, 1990.

44. National Mining Association. U.S. Mining Reclamation (ACRES). 2016. Available online: http://nma.org/ wp-content/uploads/2016/09/Coal-Land-Reclamation.pdf (accessed on 9 December 2018).

45. Office of Surface Mining Regulation and Enforcement. Annual Report 2012. Available online: http://www. osmre.gov/resources/reports/2012.pdf (accessed on 9 December 2018).

46. Estep, B. Kentucky Coal-Industry Reclamation Compliance Up Slightly, but Below Earlier Levels. Lexington Herald-Leader. Available online: http:/ / www.kentucky.com/news/state/article75950362.html (accessed on 9 December 2018).

47. Coal Mine Reclamation: Federal and State Agencies Face Challenges in Managing Billions in Financial Assurances. Government Accountability Office. Available online: https:/ /www.gao.gov/assets/700/690476. pdf (accessed on 9 December 2018).

48. Gorton, W.T. State and Federal Reclamation Bonding Programs: Lessons Learned and Current Challenges; Interstate Mining Compact Commission: Washington, DC, USA, 2013; Available online: http:/ /www.imcc.isa.us/ Bill\%20Gorton\%20Paper.pdf (accessed on 9 December 2018). 
49. Bonogofsky, A.; Jahshan, A.; Yu, H.; Cohn, D.; MacDonald, M. Undermined Promise II; National Wildlife Federation, the Natural Resources Defense Council, and the Western Organization of Resource Councils: Billings, MT, USA, 2015; Available online: http:/ / www.underminedpromise.org/UnderminedPromiseII.pdf (accessed on 9 December 2018).

50. Nair, A.S. Peabody Chapter 11 Tops String of U.S. Coal Bankruptcies; Reuters: London, UK, 2016; Available online: http:/ / www.reuters.com/article/us-usa-coal-bankruptcy-idUSKCNOXC2KQ (accessed on 9 December 2018).

51. Mufson, S. Cleanup Obligation Is Core to Plan for Coal Giant Alpha to Exit Bankruptcy. The Washington Post. 8 July 2016. Available online: https://www.washingtonpost.com/business/economy/cleanupobligation-is-core-to-plan-for-coal-giant-alpha-to-exit-bankruptcy /2016/07/08/29cc10be-4491-11e6bc99-7d269f8719b1_story.html (accessed on 9 December 2018).

52. Abandoned Mine Land Reclamation Fund Reauthorization Implementation. Available online: https:/ / www. govinfo.gov/content/pkg/FR-1994-05-31/html/94-12566.htm (accessed on 9 December 2018).

53. Richards, H. After Bankruptcy, Arch Coal Will Put Up Cash to Guarantee Mine Cleanup. Casper Star-Tribune. 13 September 2016. Available online: http:/ / trib.com/business/after-bankruptcy-arch-coal-will-put-upcash-to-guarantee/article_502daaac-f1b1-5aaa-9315-ee0e196a640e.html (accessed on 9 December 2018).

54. Rucinski, T. Arch Coal Agrees on Mine Cleanup Coverage Plan to Exit Bankruptcy; Reuters: London, UK, 2016; Available online: http:/ / www.reuters.com/article/arch-coal-bankruptcy-idUSKCN11I2HP (accessed on 9 December 2018).

55. Deutsch, D.E. The Coal Industry: Emerging Issues in Bankruptcy Cases; Chadbourne \& Parke LLP: New York, NY, USA, 2015; Available online: http://www.chadbourne.com/Coal_Industry_Emerging_Issues_Bankruptcy_ Cases_projectfinance (accessed on 9 December 2018).

56. Paterson, L.U.S. lawmakers want to ban self-bonding. Inside Energy. 16 June 2016. Available online: http: / /insideenergy.org/2016/06/16/u-s-lawmakers-want-to-ban-self-bonding/ (accessed on 9 December 2018).

57. Abandoned Mine Land Reclamation Fund Reauthorization Implementation. 59 Fed Reg (codified at 30 CFR 795,850 , et al.).

58. Office of Surface Mining Regulation and Enforcement. Fiscal Year 2016 Grant Distribution. Available online: http:/ / www.osmre.gov / resources/grants/docs/FY16GrantDist.pdf (accessed on 9 December 2018).

59. Dixon, E.L.; Bilbrey, K. Abandoned Mine Land Program: A Policy Analysis for Central Appalachia and the Nation; Appalachian Citizens' Law Center: Whitesburg, KY, USA, 2015; Available online: http:/ / kentucky.sierraclub. org/resources/abandoned-mine-reclamation-policy-analysis.pdf (accessed on 9 December 2018).

60. Bureau of Land Management. Abandoned Mine Land Inventory Study for BLM-Managed Lands in California, Nevada, and Utah: Site and Feature Analysis. Available online: http:/ / www.blm.gov/style/medialib/blm/wo/blm_library/BLM_pubs.Par.79469.File.dat/BLMAML-Inventory-CA-NV-UT_Nov2014.pdf (accessed on 9 December 2018).

61. Wei, X.; Wei, H.; Viadero, R.C. Post-reclamation water quality trend in a Mid-Appalachian watershed of abandoned mine lands. Sci. Total Environ. 2011, 409, 941-948. [CrossRef] [PubMed]

62. Mishra, S.K.; Hitzhusen, F.J.; Sohngen, B.L.; Guldmann, J.-M. Costs of abandoned coal mine reclamation and associated recreation benefits in Ohio. J. Environ. Manag. 2012, 100, 52-58. [CrossRef] [PubMed]

63. Noto, N.A. Abandoned Mine Reclamation Fee on Coal; CRS Report No. RL32993; Congressional Research Service: Washington, DC, USA, 2005; Available online: http:/ / digital.library.unt.edu/ark:/67531/metadc807162/ m2/1/high_res_d/RL32993_2005Jul13.pdf (accessed on 9 December 2018).

64. Health Benefits of Retired Coal Miners: Hearing before the Committee on Natural Resources, House of Representatives. Testimony of Alfred Whitehouse. Available online: https:/ /www.doi.gov/ocl/hearings/ 111/HR5479_062310 (accessed on 9 December 2018).

65. Office of Surface Mining Regulation and Enforcement. Budget Justification and Performance Information Fiscal Year 2017. Available online: https://www.doi.gov/sites/doi.gov/files/uploads/FY2017_OSM_ Budget_Justification.pdf (accessed on 9 December 2018).

66. Greszler, R. Congress Can Help Pensioners, But Not Through a Bailout (Heritage Foundation Issue Brief No. 4529). 2016. Available online: http:/ /www.heritage.org/research/reports/2016/03/congress-can-helppensioners-but-not-through-a-bailout (accessed on 9 December 2018).

67. Miners Protection Act of 2016. Available online: https://www.congress.gov/bill/114th-congress/senatebill/3470 (accessed on 9 December 2018). 
68. Johnson, S. Time Is Short for Miners Protection Act. West Virginia Metro News. 29 November 2016. Available online: http:/ / wvmetronews.com/2016/11/29/time-is-short-for-miners-protection-act/ (accessed on 9 December 2018).

69. Government Accountability Office. Interior May Have Approved State Shifts to Noncoal Projects Prematurely (GAO Publication No. B-226046). 1991. Available online: http://www.gao.gov/assets/220/214425.pdf (accessed on 9 December 2018).

70. Wyoming Taxpayers Association. Abandoned Mine Land Fund. 2012. Available online: http://www. wyotax.org/aml.aspx (accessed on 9 December 2018).

71. Hancock, L. Rock Springs Could Receive Abandoned Mine Land Money. Casper Star-Tribune. 25 February 2016. Available online: http://trib.com/news/state-and-regional/govt-and-politics/state-in-line-formillion-in-mine-money/article_69d45c42-6fb1-5b6f-b763-f79bea18678e.html (accessed on 9 December 2018).

72. Government Accountability Office. Management of the Abandoned Mine Land fund (GAO Publication No. B-244654). 1991. Available online: http://www.gao.gov/assets/220/214685.pdf (accessed on 9 December 2018).

73. Office of Surface Mining Evaluation Reclamation and Enforcement's Oversight of the Abandoned Mine Lands Program, Office of the Inspector General US Department of the Interior. March 2017. Available online: https:/ / www.doioig.gov/sites/doioig.gov/files / FinalEvaluationReport\%20_OSMRE\%20AML_ 033017_Public.pdf (accessed on 9 December 2018).

74. Cao, X. Regulating mine land reclamation in developing countries: The case of China. Land Use Policy 2007, 24, 472-483. [CrossRef]

75. Kahn, R.J.; Franceschi, D.; Curi, A.; Vale, E. Economic and financial aspects of mine closure. Nat. Resour. Forum 2001, 25, 265-274. [CrossRef]

76. Hilson, G. Small-scale mining and its socio-economic impact in developing countries. Nat. Resour. Forum 2002, 26, 3-13. [CrossRef]

77. Hilson, G.; Haselip, J. The environmental and socioeconomic performance of multinational mining companies in the developing world economy. Miner. Energy 2004, 3, 25-47. [CrossRef]

78. Cheng, L.; Skousen, J.G. Comparison of international mine reclamation bonding systems with recommendations for China. Int. J. Coal Sci. Technol. 2017, 4, 67-79. [CrossRef]

79. Boomhower, J. Drilling Like There's No Tomorrow: Bankruptcy, Insurance, and Environmental Risk; Judson Boomhower: Stanford, CA, USA, 2014. 